\title{
DEVELOPMENT OF PRINTING IN NORTH CYPRUS AND ITS EFFECTS ON MODERNISATION
}

\author{
Eser KEÇECI \\ Yakın Doğu Üniversitesi, KKTC \\ eser.kececi@neu.edu.tr
}

\begin{abstract}
This study aims to explore the development of printing in North Cyprus in comparison to its development in the west. On the context of modernization, societies change constantly through the invention of new technologies. These changes, however, do not follow the same pattern in different societies. Depending on socio-economic, cultural and political situation in each society, the technological development differs. For, this is not the technology which changes the societies. Rather, it is the societies' responses to these technologies which bring the changes. Having the uniqueness of each society in mind, this research aims to explore the responses of Cypriot society to the new technology of printing and the way it differs from western societies. While in the western societies, printing initiated as a tool for spreading knowledge, the history of printing in Turkish Cypriot society was involved in political and commercial objectives in early and late 90 s respectively. In order to meet the above-mentioned objective, this research explores printing technological development, its political and ideological usage, and its effects on the modernization of the society.
\end{abstract}

Keywords: Printing, Cyprus, Modernisation

\section{KUZEY KIBRIS'TA MATBAACILIĞIN GELIŞSIMII VE MODERNLEŞME}

\section{$\ddot{O Z Z}$}

Toplumların modernleşme sureçleri yeni teknoloji ve buluşların kullanıma geçmesiyle yakından alakalı olduğundan, gelişim; kültürel, sosyo ekonomik ve politik nedenlerden doalyı her toplum için farklı yönde ilerlememektedir. Bunun nedeni de toplumların bu gibi değişikliklere hangi yollaradn geçip nasıl adapte olduğudur. Her toplumun kendi içerisinde farklılıklarını göz önünde bulundurarark bu çalışma, Kuzey Kıbrıs Toplumu'nun, kendi tarihi içerisinde, matbaacılığa geçiş sürecini, Batılı toplumlarla benzeşen ve ayrılan yönleriyle ortaya koymaya çalışmaktadır. Batı toplumlarında matbaacılık, bilginin yayılması için bir araç olarak başlarken, Kıbrıs Türk toplumunda basım tarihi ilk başlarda siyasi ve ideolojik amaçlara hizmet etmiş 90'lı yıllardan sonra da ticari amaçlar için kullanılmıştır. Çalışmada Kuzey Kıbrıs’ta matbaanın gelişim süreci Avrupa ile karşılaştırmalı olarak işlenmektedir. Dolayısıyla, sözkonusu amacı karşılamak için matbaacılığın gelişimini, politik ve ideolojik kullanımını ve toplumun modernleşmesine etkileri ortaya konmaktadır. Araştırma, karşılaştırmalı alan yazın kaynaklarından yararlanılarak ortaya konmuştur.

Anahtar Sözcükler: Matbaacılık, Kıbrıs, Modernleşme

\section{INTRODUCTION}

The development of printing in Cyprus has significant variations with the past in consideration within the modernisation adventure. Following the major economic and social developments in West, the printing was invented and started to be used widely through big reform movements; in Cyprus, the printing was used to meet the political needs. Acording to the references, the invention of printing in 1450 s had a major place in the European history and covered under the resources as a significant development, yet the subject was not covered in the same way under the Cypriot historical researches. 
The first printing in Cyprus was known to be established in Larnaca in 1878, which indicates a 400year gap with Europe. Additionally, the press history in Cyprus was integrated with politics and served as a tool in the dissemination of an ideology to the public.

This study aims to explain the development of printing in North Cyprus in comparison to European countries, which are defined as West. Since the development and use of printing in Cyprus is parallel with the Cyprus Political history, both contexts were given together.

In the European History, the most significant innovation of $15^{\prime}$ th ceuntry was the invention of printing. On the other hand, in Cyprus, first publishing house was estaplished in 1878, which it shows that there is 400 years time gap between them. After the World War II, the world has divided in to two blocks and West has emerged before the East. If we compare East and West together, Western Countries has developed earlier then the Eastern ones, because of the social and political developments. These developments can be associated with the capitalist echonomy and democracy in the political maturation. Afther the World War II, the reasons of the Western countries easy shift to capitalist echonomy, can be based on the 15 'th ceuntry positive evolutions on religion, cultural and thecnological issues. Printing which is the main focus of this study is one of the most significant technological inventions of the mentioned ceuntry.

\section{LITERATURE REVIEW}

After the sources has been scanned about the North Cyprus and European print history, all the texts has been researched which are include print wors in the Cyprus history books and magasines. In addition to these, the interviews with the old print house owners families examined in the old newspapers and magazines.

\section{METHODOLOGY}

Afther the results of a general subject research, a comperative analysis have been done between Europe and North Cyprus on print history and its effects on modernisation.

\section{DISCUSSIONS}

In $15^{\text {th }}$ century, the island of Cyprus was under the mandate of Venetians known as dominant to the Orthodox Christians. The sovereignty of Ottoman Empire was started in 1571 and a pluralist structure was created in Cyprus in terms of religion through the arrival of Muslim population to the island. Moreover, the Orthodox Church was vested both administrative and economic privileges in the island. The peaceful environment of the island where the Muslim and Non-Muslims were living together were deteriorated with the rise of Independent Greek State in $19^{\text {th }}$ century, the influence of Helen nationalism on the Greek Cypriot community and regression of Ottoman State. Afterwards, the island was leased to the British together with its population, so the island become the biggest Christian subject over night as being the biggest Muslim subject before. During this period, many people particularly intellectuals were migrated to Anatolia. Post-lease of island to the British administration, the printing used by the West since $15^{\text {th }}$ century was introduced to Cyprus.

Although there was a lithography used for the state documentation during the Ottoman Period, the first printing house in Cyprus was established in Larnaca in 1878 and Nicosia in $1882^{1}$. In accordance with the studies of Hüdaoğlu, during the Ottoman Period in Cyprus "this printing house using lithography were under the control of government and was used to copy the official documents. The British Administration established the Nicosia state printing house in 1882 that uses metallic letters... prior to the establishment of official British printing house, the printing house in Larnaca where the newspaper 'Cyprus' was printed was established in 1878” (Hüdaoğlu 2011:57). The name of that printing house

\footnotetext{
${ }^{1}$ During the Ottoman period, "since there was no printing house of Turkish Cypriot and Greek Cypriot communities, the Turkish Cypriots wanting their articles or poems published in a newspaper, were sending such to one of the newspapers published in İstanbul"." (Dedeçay 1989:19).
} 
was "Henry King and Co." (Cyprus Turkish Journalist Association 2011:10)2 ${ }^{2}$ Starting from the first week of British Administration in 1878 until the end, the first newspaper that carried on until 1960 was 'Cyprus Gazetta'.

As the official media organ of British Administration, this newspaper was first published once in two weeks and then once a week in English, Turkish and Greek as separate papers. Moreover, it is known that British Administration brought Turkish letters from İstanbul in order to use in their British stateprinting house. According to Dedeçay, the Cyprus Gazetta continued to be published separately in three languages until 1930 and after 1930, it was only published in English. This newspaper, which was published under the name of Ceride-i Resmi in Turkish comprising the official decrees concerning the amendments on the Cyprus legislation taken by the British Administration, is one of the vital information resource for the people that make research on Cyprus.

Considering the researches of Dedeçay, the first printing house owned by the Greek Cypriots were established in 1879, Larnaca, which was the capital at that time. Since there was no printing house of Turkish Cypriots until 1891, the Turkish Cypriots were using the printing houses owned by the Greek Cypriots. In 1891, "the printing house of Turkish Cypriots considered as the first that called Kiraathane-i Osmani was started to operate (Dedeçay: 1988, 38-44). Similarly, the book of Dedeçay notes that the number of printing houses during 1886-1920 varied between 6 and 29.

In his book called 'Kıbrıslı Türk Toplumunun Geri Kalmışlı̆̆ı', Ahmet An included an article of Dr. Hafiz Cemal, a valuable Turkish Cypriot person who took the surname of 'Lokman Hekim' in Turkey, published in the newspaper of Mirat-1 Zaman in 1909 where he noted the following information. "... I had the chance to visit all towns and villages of this beautiful island where I observed the status and basic needs of Turkish Cypriots closely. I could say that Turkish people are 99\% illiterate living without art whereas the Christians are 99\% qualified in terms of knowledge and art" (An 2006:15-16). In the following sections, it noted that there were not any Turkish doctor, pharmacists and even a midwife with a diploma in any village or town of island, and the book compared the skills and artisanship of Turkish people with Greek. Turkish Cypriot people was living off by making şamişi (a kind of traditional Cypriot dessert), yoghurt, milk pudding, kerchief, juice and working as blacksmith, bath attendant, servant, carter, worker and farmer, while Greek Cypriot people were making a living as a doctor, pharmacist, lawyer, factory owner, mechanic, coachman, car dealer and pressman. Dedeçay indicated that between the years of 1889 and 1946, the 'publishing a newspaper' and 'working in the printing houses' were considered as the profession with no foreseeable future, a few Turkish people were interested in the professions of printing or publishing newspaper. The reasons for such circumstances were that the villagers, workers and shopkeepers comprising the Turkish Cypriot communities were not or barely literate and the infrastructure of road connecting Nicosia with other towns and villages was not completed, which made the distribution of newspaper to the villages or towns impossible. However, in the following years, "Turkish Cypriots increasingly started to envy the success of Greek Cypriots in printing and publishing and also the British colonial administration showed encouragement accordingly, hence the Turkish Cypriots started to perform the professions of newspaper publishing and printing" (Dedeçay 1989:21).

As indicated before, the first Turkish printing house was Zaman Printing House founded in 1891, Laleli. Zaman Printing House, which was owned by the Haji Derviş Efendi, a wealthy and religious sultan supporter, was the media organ of Kuraathane-i Osmani. The senior reporter of the newspaper was Muzaferüddin Galip, who was a Young Turk from İstanbul as there was no such profession among the Turkish Cypriots. In the course of time, with the introduction of more intellectuals under the newspaper, there were divergences with the Haji Derviş Pasha, who was awarded with the degree of 'Mir-i Miran' by the sultan due to his accomplishments. However, after a short while, the writers of Zaman newspaper "started to publish the New Zaman Newspaper rather than Zaman due to the censorship of Ottoman administration" (Cyprus Turkish Journalist Association, 2011:20).

\footnotetext{
${ }^{2}$ Ümid Newspaper, the first newspaper published in the Ottoman Turkish language is knows that was published in Henry King and Co. Printing House.
} 
Ahmed Tevfik, a Young Turk supporter, was the owner and editor-in-chief of another newspaper, Mirat Zaman Newspaper. This newspaper was printed in the Greek Cypriot printing house for a long time. The Greek Cypriot printing house did not want to print the Mirat-1 Zaman anymore due to the news included as an answer to some Greek Cypriot newspapers, and the newspaper found a machine with their own means and continued to publish the newspaper under very difficult conditions. Pursuant to the citation by Dedeçay from the book of İsmet Konur called 'Kıbrıs Türkleri', " since Ahmet Tevfik Efendi did not have enough money to build a printing house, he was printing his own newspaper by lining a couple of kilos letters himself and pressing a heavy marble on top of them"(Dedeçay 1989:42).

According to another information of Dedeçay quoted from İsmet Konur, there was manual machinery owned by the Sünuhat Newspaper, which was the supporter of sultan at first and then become the supporter of Committee of Union and Progress. In the same text, Prof. Ahmet Şükrü Esmer, the son of Mehmet Arif Effendi, who was the owner of newspaper, noted the following concerning the printing machine. "... The technical facilities of our newspaper were not that many. We used to have a manualprinting machine. We used to find a porter to operate the machine after the newspaper was bound, which we were only printing around one thousand"(Dedeçay 1989:43). Esmer also stated that there was a freedom of press in Cyprus and the British were tolerant.

Between 1907-09, the İslam Newspaper owned by Dr. Hafiz Cemal Efendi was printed at the Hamidiye Art School Printing House and "... Other than providing services as a doctor in villages, Dr. Hafiz Cemal was also known to register subscribers for his newspaper İslam. In order to publish İslam Newspaper, Doctor Hafiz Cemal purchased a couple of kilos (in variation) letters and equipment for the printing house from London)"(Dedeçay 1989:43).

The book published by the Cyprus Turkish Journalist Association in 2012 called History of Cyprus Turkish Press noted that Vatan Newspaper (1911) was being printed in Vatan printing House, which was one of the early printing houses of the time and the Doğru Yol Newspaper owned by Ahmet Raşid was being printed by the printing machine of Hasan ve Hüseyin Cengizoğulları. More detailed information related with the subject were obtained and Ahmet Tenay, the son of Shevket Bodamyalizade as the owner of Vatan Newspaper, provided the following remarks concerning the printing house of his father. "Our two-storey home with its balcony and chalet facing AyLuka was on Tabak Hilmi Street in the Kuru Çeşme neighbourhood. My father created a small printing facility, which was 50 square meters, on the ground floor to publish his own newspaper. There were only a machine with a handle, composing room cases and lead letters in Ottoman script. Then he brought another hand-operated machine with wheels and the small machine then was only used for little things. After operating this Vatan printing house for two years, my father initiated to be a judge and sent the equipment to Hasan and Hüseyin Cengiz brothers. Cengiz brothers moved this printing house to Asma Altı and served many years under the name of Cengiz printing house" (Dedeçay 1989:44) ${ }^{3}$.

After a while, Hüseyin and Hasan Cengiz brothers terminated their partnership with the reason that the printing house was not generating sufficient income for both families. The responsibility of Vatan newspaper as well as the Cengiz printing house was left to Hüseyin Cengiz. An article called 'Kıbris Türk Basınında Bir Kepçe: Matbaacı Akif Bey' from early 1920s about Akif Bey, the assistant of Hüseyin Cengiz was found as translated by Harid Fedai. The introduction section of article stated that there was an economic crisis and Akif Bey's remark about the requirement to be put forward in order to overcome such poverty. Furthermore, the article delivered the experience of Mehmet Akif after he went on the road with his bicycle without 'bell, light, brake'. This journey, which was just a routine for the Printer Akif Bey, was as follows;

"In the beginning of the month, I took my bike with me and rode to

Larnaca. I stopped by our subscribers close to the main road and then

\footnotetext{
${ }^{3}$ Dedeçay noted that he got such information through his interview conducted with Ahmet Tenay on 15.07.1988.
} 
reached to Limassol. After resting there for a couple of days, I went to the town of Pafos. I had to stay there for a few days. In order to pay money for the hotel, I stayed in the room of mudarris within the madrassa with the consent of Hocazade Daha Effendi, who is my friend. Then, I went to Poli and after staying there for two nights, I left my bicycle there and visited the villages of Polatusa, Melataya and İstinco ... "(Fedai, 2005:41).

Then he visited Sarama, Anotyu Villages, Lefke, Melandra, Liso and back to Poli again. He continued his journey from Poli and via Hirsofu, he visited Tera, then Arodez, Strumbi, Kukla, Susuz, Ayyorgi, Ciyas, Aynikola, Malya, Piskobu, Limassol, Pendakomo, Tatlısu, Köfünye, Alaminyo, again Köfünye and Nicosia. The Pressman Arif Effendi stated that this journey was taking a month and "regardless not spending to much from the money collected, the amount that I brought back was not more than ten. This amount was the six-month expenditure of the newspaper excluding the labour force"(Fedai 2005:42).

Considering the quotes from this article, the public was poor and the income expected to be made from the printing was acquired in very difficult conditions. Additionally, when it is thought that the transportation and postal services in Europe were completely in place in the first quarter of twentieth century, the conditions for the modernisation of Turkish Cypriots become much clear.

Since the switch to media form press in Europe as well as the foundation of first printing house in the island were in $19^{\text {th }}$ century, we could consider that the literacy had developed late in Cyprus. The level of literacy was improved during the British Administration and both quantitative and qualitative reforms were happened in the education structure. At that time, "there was a real boom in the number of school. In 1881, the number of Greek Cypriot schools was 99 and went up to 273 in 1901, while the number Turkish Cypriot schools increased to 144 to 71"(Kızılyürek 2002:78). Moreover, the first books published in Europe was the Bible that was translated to various languages after the major reforms, while the same was the newspaper in Cyprus and almost the printing history started with this milestone. The first newspapers in Europe was served as the letters of news and then become rather thematic newspaper; yet the first newspapers published by the Turkish Cypriots were short-lived and did not create that much influence on the social base.

In 1930s, the newspapers in the Cyprus Turkish press under the British Administration were completely published with Latin letters. The Republic of Turkey had sent a printing house to Cyprus for Söz newspaper. The Söz newspaper owned by Mehmet Remzi Okan reflected the political views of Ankara government which was anti-British colonialism was the first newspaper, which was published with new letters ${ }^{4}$ in 1931 after the alphabet reform in 1928. When remzi Okan passed away, the sisters of Beria, Vedia and Bedia continued to publish the Söz newspaper in accordance with the will of their fathers. Therefore, Vedia had become the first female publisher and Bedia the first female editor-inchief in the history of Cyprus Turkish Press.

Beria Remzi Özoran told the following about the Söz newspaper;

"Our home in Nicosia was at first in the new street across the Mecidiye Street. We were using two rooms to print the newspaper. Then we moved to the house in the blind alley just next to the Arabahmet Mosque. In 1930-31, we moved to the house in the garden of dervish lodge and then the house in Köşklüçiftlik next to Dr. Küfi Bey. We used to help my father in the writings and adjustment of the newspaper. Our income source was the newspaper. The newspaper was not sold in any place but only sent to the subscribers. We had approximately 1800 subscribers. When the newspaper became daily, the journalists started to distribute the newspaper. We even had subscribers in the remote villages. In the beginning of the month, my father used

\footnotetext{
${ }^{4}$ The cost of Latin letters ordered by Okan, was paid by the Republic of Turkey with the direct order of Atatürk. Similarly, with an order of Atatürk, Okan was congragulated for his contributions to the war of independence through a letter sent by the director of press Ahmet Ağaoğlu.
} 
to go to the villages and towns together with a driver named Halil, and he was both working to get new subscribers as well as collect money"(Dedeçay 1989:49).

Later on the article, Özoran indicated that following the success of the war of independence, the public was rushing to the windows of Söz Newspaper to read the telegram news and even the windows were ended up broken. Thus, the telegram news were copied and sold so the printing house made some profit ${ }^{5}$.

In the article of Harid Fedai called 'The Findings from Cyprus in the First Decade of Language Reform', the Söz Printing House was mentioned as the pioneer of alphabet reform in Cyprus. Additionally, the article also covered the quotes from the person-in-charge Beria Remzi Özoron in relation with the new printing letters.

"When the related company accidentally included the name of Söz Newspaper under the invoice of Latin printing letters ordered from Germany for the Turkish newspapers, the young Republic of Turkey appreciated this and that cost was covered by the government as a gift to the Turkish Cypriots; which led Remzi Okan to perform his journalism profession within his heart" (Fedai 2002:106).

After 1924, a governor as a Royal colony governed Cyprus. During that period, the Turkish Cypriots were divided into two groups; the Evkaf supporters (Muslim religious Foundations) considering themselves as Muslim British nationals and Democrats, who support the Turkish nationalism. Such political separation and organisation were reflected on to all kinds of political, economic and cultural aspect within the Turkish Cypriot community.

Within this perspective, the tendencies of printing houses founded by the Turkish Cypriots were obvious from the context of their newspapers. Particularly after the printing houses started to use Latin letters, there were conflicts among the newspapers owned by Turkish Cypriots and Greek Cypriots and Turkish since 1930s, which was the period considered as the second phase of the history of Cyprus Turkish Press. Moreover, the British Administration adopted 'the Cyprus Press Criminal Code' in 1929, with the aim to prevent the press to publish against the Colonial Administration and United Kingdom. In 1931, the British Administration adopted another law regarding the press, hence the printing houses. This law covered the following:

"This Law shall be the law for the newspaper, book and printing houses. Pursuant to this Law, every person to publish a newspaper shall primarily obtain an authorization from the undersecretariat of the colonial administration and shall pay 200 Cyprus Lira in cash as a warranty. This Law shall oblige the publication of every decree of government in the newspapers without any charge."(Cyprus Turkish Journalist Association 2011:66). “

The British Colonial Administration, which was under pressure aimed to make the publishing, printing of a newspaper difficult for both communities.

In 1931, the Megali İdea and hence Enosis ${ }^{6}$ had taken whole Greek Cypriot community under its influence. The 1931 Uprising was an explicit indicator of this movement. Therefore, while the world was struggling with the economic crises of post-World War II between 1930-1958, Cyprus was going through a period where the British laws were in force and the idea of Enosis was gaining momentum. This period was considered as a rigid dominance period on the freedoms. The suspension of political activities and censorship on the printing houses were the only issues covered under the research subject. The censorship of press had a negative impact on the printing houses owned by the Turkish Cypriots. Due to the laws adopted by the British administration and strict measures after the 1931 uprising, the Turkish Cypriot printing houses were either shut down or survived with significant struggles until 1934. There were no new newspaper launched in the Cyprus Turkish press until 1934;

\footnotetext{
${ }^{5}$ For more information regarding the printing history of family, see. The interview of Havadis newspaper with Bedia Okan on 05.03.2012.

${ }^{6}$ The ideal of Greek Cypriots for the annexation of island to Greece.
} 
only Masum Millet, Söz and Hakikat Newspaper- closed in 1932 were continued their publications. In accordance with the book published by the Cyprus Turkish Journalist Association, the newspapers printed in the printing houses were far from delivering ideas and did not include any critical articles; yet included informative works on the world news.

After 1939, Turkish Cypriots started to be influenced by the political and social ideas in Turkey and some newspapers printed in İstanbul were brought to Cyprus and particularly Söz as well as some other newspapers published articles cited from the Turkish newspapers.

The British Administration eliminated its rigid measures and dominant attitude by the outbreak of World War II (1939) and then the Turkish Cypriots were able to be in political activities. Within this framework, despite of the shortage and poverty caused by the World War II and harsh conditions, Dr. Fazıl Küçük founded Halkın Sesi, the newspaper that put the most relentless fight against ENOSIS and colonialism. Halkın Sesi has been the most long-running newspaper in the Cyprus Press, that still available. The newspaper first printed in the Fikri printing house and then Söz Printing House in 1942. Then the Halkın Sesi Printing House was established, where the newspaper was printed there. Dedeçay covered an article directly from Dr. Fazıl Küçük in his book. This article explained the solutions that Dr. Fazıl Küçük found when the Halkın Sesi newspaper was suspended for three months and British Administration decided not to allocate any paper for the printing of Halkın Sesi with the justification that a news newspaper was launched that would meet the needs of community. When;

"...the British administration told me to shift on my own, they have left me with black market. While the paper batch given by the government was £1 CL, it might be $£ 10$ Cyprus Lira in black market. Many times, it cost us $£ 20$ CL... When we were not able to find paper, we were referring to the small grocery shops and there were times that we used grocery store papers to print the newspaper. We still keep them in our collections and whenever I go through those, I still remember those dark days as it is now" (Dedeçay 1989:58).

It was known that during the World War II and especially between 1942-45, the printing houses in Cyprus were having difficulties in finding paper to print.

On the other hand, the Greek Cypriots acted in parallel with the modernisation and through their observations from Europe, they brought the nationalism to the island via nation-state and established the EOKA organisation with the ideal to annex the island with Greece. The main content of Greek Cypriot newspapers were Helen nationalism and longing of motherland. Even the most liberal newspapers were called 'Enosis'.

The establishment of EOKA also affected the Cyprus Turkish press. The Greek Cypriot companies that distributed the Turkish Cypriot newspapers prior to EOKA in 1955 stopped such activity. Therefore, the Turkish Cypriot newspapers were not been able to sent to places other than Nicosia and the number of readers dropped. Some newspaper owners managed to distribute their newspapers with their own sources in order to cover the expenses and not to have any drop in the readers. Dedeçay included the following remark of Kemal Deniz, the owner of Ateş Newspaper:

"We were a daily newspaper and then had to be weekly as we did not have a printing house. This continued until 1950. The biggest problem was the distribution. There was no such distribution as now when we were publishing the newspaper. The Greek Cypriots were conducting the distribution ... what I was holding on the most was; I was at the farmers Union and visiting villages. I kept getting new subscribers from the villages. Thus, I was printing an extra of thousand copies and giving those away for free. The foreigners read their newspaper every day but our community does not have such habit. I tried to inculcate this. First I was giving a speech and then giving them one copy of newspaper each" (Dedeçay 1989:62).

In the further sections of article, Deniz indicated that the crux of the problem was the lack of printing houses and staff, yet they did not have any. Additionally, the population and number of readers were 
not that many while he emphasized that a newspaper on its own could not survive without a printing house.

Another printing house established in 1947 was the Bozkurt Printing House. In the article called 'Kurucusu Cemal Togan'in Kaleminden, Bozkurt'un Dünü ve Bugünü', Togan Bozkurt stated the following about his printing house. "We established our printing house in 1947 and are now working towards modernisation, we wanted to publish a newspaper and serve to the public through our printing house in the beginning of 1951"(Dedeçay 1989:69).

The first colour printing was introduced with the İstiklal newspaper in $28^{\text {th }}$ October $1949^{7}$. İstiklal was printed with a red heading since its first issue. Additionally, there was a picture of Atatürk in the middle of a colour Turkish flag. "The İstiklal Printing House known as the Ozanlar printing house did not have a cliché workplace. The Greek Cypriot named Elefteriades working in the Intelligence Department was being paid with an exclusive payment" (Dedeçay 1989:64).

In consideration with the aforementioned, the printing in Cyprus arisen in the political domain and was affected with the conflicts among the politicians. For instance; Dr. Fazıl Küçük and Rauf Raif Denktaş were in conflict due to having the same printing houses for their newspapers. The Greek Cypriot press was criticizing Denktaş, who was the Head of Cyprus Turkish Federation, and he was answering such criticism with his articles in the Nacak Newspaper printed in the Halkın Sesi Printing House. Since it was a weekly newspaper, the articles of Denktaş were published with a wide coverage, and hence his name was on the headings. Kutlu Adalı explained as;

"On one night, Dr. Küçük could not contain himself and said 'What is this headline? Denktaş is on the headlines every week. This causes misunderstanding.' This is not possible. When we explained him the reason, he seemed as if he got the point. However, he got offended from an article that I had written the next week, and attacked me in front of his employees and employees of Nacak at his printing house. He ordered to stop the printing of newspaper. He said 'I will not print your newspaper, do whatever you want"' (Dedeçay 1989:72).

The period between 1958 and 1974 are defined as the years of struggle in the Cyprus Turkish history. Therefore, each written inventory printed in the printing houses throughout these years were considered as the materials transformed from the press of idea to the press of struggle, and the newspapers of those years reflected such circumstances.

During those years, the number of newspapers published as the political party media organ increased and the newspapers with opponent ideas were not printed in the same printing houses. Therefore, the printing houses and technicians were considered as a part of the period politics. Sometimes there were various arguments among the parties. For instance, the arguments between Dr. Fazıl Küçük and Rauf Raif Denktaş affected the Zafer Printing House. Dedeçay delivered the citation of Kutlu Adalı; "The ones, who put pressure on Nacak, did the same thing to Zafer... On one night, their men even placed a bomb to the printing house... due to such pressure, the typographers and pressmen just scared and left. Then the problem of finding a technician had arisen" (Dedeçay 1989:81).

As is known, with the events of $27-28^{\text {th }}$ January 1958, the Turkish Cypriots hold a public demonstration for the first time, and a lot had happened respectively. The reason behind those events was the report published in the Bozkurt newspaper on $27^{\text {th }}$ January 1958 with the heading 'Britain accepted the annexation' (Cyprus Turkish Journalist Association, 2011:104). Therefore, the press could be considered as a major influence on the organisation of this organisation. With the development and popularity of printing, the press had an access to the public and used them as a tool to deliver a reaction. The press in Europe was bringing people together and raised their awareness before and after the World War II; and was used as a crucial tool to trigger or promote the events accordingly; yet the same was applicable with a 10-15 year gap in Cyprus.

\footnotetext{
${ }^{7}$ For more information, see. "Cyprus Turkish Press History" P. 92.
} 
Another important aspect of 1958 was the official establishment of Turkish Resistance Organisation. During those times, the printing houses were particularly publishing the political cause newspapers and putting their support. Especially the Nacak Newspaper printed at the Halkın Sesi Newspaper and other newspapers released publications to organise the public for the resistance and rationalise the national struggle.

On 1960, the bi-communal Republic of Cyprus was founded in 1960 and the Cumhuriyet Newspaper, printed in a printing house owned by the Turkish Cypriots, had become a rear newspaper defending the existence of this Republic. Therefore, the political status of Fikri printing house was able to be identified.

With the outbreak of 1963 events, the press of national struggle had become more widespread and maintained this position for a long time. Following the attacks of Greek Cypriots to annex the island with Greece on $15^{\text {th }}$ July 1974, Turkey intervened to the island on $20^{\text {th }}$ July. After all happened, the printing houses and hence newspapers have covered articles related with the inter-communal talks, progress of talks and the outcomes.

In 1974 and after, the increase in the number of images on the newspapers might be considered as one of the significant developments in printing. As is known, in Europe, the number of images on the inventories printed in the printing houses had increased post-World War II, however such development occurred in the Cyprus Turkish printing after 1974. "The increase of the images published in the Turkish Cypriot newspapers was started after 1974 when the printing houses located in North Cyprus gradually switched to offset technique "(Dedeçay 1989:28).

Post-1974, the Cyprus Turkish Press entered into a differentiation process, which the press aimed to be political and keep up with the capitalising world and that the commercial press began to show its effect. " The importance of trade, expansion of goods market, increase in workplaces and employers, transcendence in education and evolution of life into modern forms caused the transformation of press" (Hüdaoğlü 2011:97).

As Kiz1lyürek covered in his studies, in the $19^{\text {th }}$ century, a new middle class was arisen with capitalism among the Greek Cypriot community. The prominence of Greek Cypriot community during the capitalisation process reflected the fact that there was no joint modernisation process in the island; on the contrary the unequal development was generated at the early stages of modernisation. Such situation was the reason behind the breakdown of equality in terms of economy and culture between the communities later on. However, the Turkish Cypriots started to stand on their own feet and " $\ldots$ as a natural outcome of market dominance, they started to bring the emphasis of 'Turkish Cypriot' to the fore, reject the mandate and re-establish their identity in the guidance of Turkish Cypriot nationalism" (Hüdaoğlu 2011:99).

During the period of Peace Operation (1974), there were only three newspapers published by the Turkish Cypriots. These printing houses operated within the given period were Bozkurt Printing House, Halkın Sesi Printing House and Zaman Printing House.

Nevertheless, with the introduction of daily newspapers from Turkey to the island after 1975, the public began to read newspaper and be aware of the world, yet this diminished the effectiveness of Cyprus Turkish Press. However with the establishment of Turkish Federated State of Cyprus in 1975, the political parties began to be established and the printing houses activities were increased through the publications of the media organs and supporters of political parties.

Moreover, the printing house that performed colour printing with the offset technique for the first time was established in 1982 as one of the development in Cyprus Turkish printing, which commenced the technology era compliant printing. "The first colour printing machine in Cyprus was at the printing house of government located in Nicosia in the year of 1952. However, the printing house that used the 
offset technique for the Turkish Cypriot press was the Kıbris Postasi printing house founded in 1982, which provided the Kibris Postası newspaper in colour" (Cyprus Turkish Journalist Association, 2011:130).

After 1983, the Turkish Cypriot press gained more momentum. Another significant development in the modern Turkish Cypriot printing was the establishment of a printing house and newspaper in Cyprus by Asil Nadir, an important businessman of time, in the compliance with European standards. In consideration of $90 \mathrm{~s}$, in order to deal with the unfair competition from the Turkish newspapers, the Cypriot printing houses began to print political, magazine, and sports supplements together with the newspapers. On the other hand, offset printing technique was innovated by, Ira W. Rubet and Casbar Herman who was American in 1904 which was nearly 450 years after the Gutenberg invention.

By 2000s, "there were generally newspapers printed with relative printing technique. The number of daily newspapers printed at the existing printing houses is fourteen. Such newspapers follow the agenda in Cyprus as well as reach to the world via the internet by the state-of-art technology" ”(Cyprus Turkish Journalist Association, 2011:131).

\section{CONCULUSIONS}

In consideration with the printing history of Europe, Gutenberg designed a machine for letterpress with mobile parts in $15^{\text {th }}$ century, and hence started the printing history. At the same time, this invention had become a significant tool in the generation and dissemination of information by the time of Renaissance to reforms and then the age of enlightenment. In terms of the Turkish Cypriot printing history, the establishment of regular postal services for the general public, the production and dissemination of news and the orientation towards printing had been developed and become popular on a political platform by the $19^{\text {th }}$ century. Such finding is generated from the information that Turkish Cypriot intellectuals under the British administration had established the first printing press in Cyprus through the inspiration of first newspapers introduced with the modernisation and reform movements in the Ottoman Administration in the $19^{\text {th }}$ century. Therefore, the idea and ideology journalism had started. Particularly, the Turkish Cypriot printing press and hence the press had a crucial role in making the Turkish Cypriots heard in the world from the 63 events that started 3 years later from the foundation of the Republic of Turkey, until 1974. Today, regardless all embargoes, it continues to be the representative of Turkish Cypriots.

There is a 4-century gap between the printing history of Europe and Turkish Cypriot. Printing history. From the beginning of Turkish Cypriot printing history until 90s, the purpose for the utilisation of printing history had always been political and then faced towards the commercial press by the $90 \mathrm{~s}$ and then the printing had reached to the world standards upon the completion of capitalisation.

There are variances within the modernisation period of each society. This study aims to reflect the transition to printing press within the history of Turkish Cypriot Community from the perspective of similarities and differences with the Western societies. Consequently, regardless the time gap between the West and Cyprus in the introduction of printing, the Turkish Cypriot printing has adapted itself to the Western technology after various concerns and processes. As now each newspaper has its own printing house in the North Cyprus, there are also private printing houses for other periodical or nonperiodical publications and the printing houses owned by the printing advertising agency compatible with today's technology.

\section{REFERENCES}

An, Ahmet. Kıbrıs Türk Toplumunun Geri Kalmışlı̆̆l, Şadi Kültür ve Sanat Yayınları, Girne, 2006. Atun, Suna. İstiklal Gazetesinin Kıbrıs Türk Edebiyatına Katkılarl, KIBATEK-YDÜ XI. Uluslararası Edebiyat Şöleni, Yayıma Haz: İsmail Bozkurt, Ali Nesim, Şevket Öznur, Yakın Doğu Üniversitesi Basımevi, Lefkoşa, 2005. 
Dedeçay, Servet Sami. Kıbrı'ta Enforamsyon Veya Yazılı ve Sözlü Basın, Lefkoşa Özel Türk Üniversitesi Yayınlarl, Ortam Ofset, Lefkoşa, 1989.

Demiryürek, Meral. Kıbrls Türk Tiyatrosu Tarihinden:Safa Yahut Netice-i İbtila, III. Uluslar arası Büyük Türk Dili Kurultayı Bildiri Kitabl, Lefke Avrupa Üniversitesi Yayınları, 2008.

Demiryürek, Mehmet. Türk Harf İnkllabı ve Kıbrıs'ta Basılan Türk Alfabeleri, III. Uluslar arası Büyük Türk Dili Kurultayı Bildiri Kitabı, Lefke Avrupa Üniversitesi Yayınları, 2008.

Fedai, Harid. Kıbrıs Türk Kültürü, Bildiriler I, Kıbrıs Türkünün İlk Mizah Gazeteleri: Kokonoz ile Akbaba, Selçuk Üniversitesi II. Milletlerarası Türk Halk Edebiyatı ve Folkloru Kongresi, Konya, 1921 Ekim 1992, Özyurt Matbaasl, Ankara, 2002.

Fedai, Harid. Kıbrıs Türk Kültürü, Bildiriler I, Dil Devriminin İlk On Yılında Kıbrıs'tan Saptamalar, Türk Dil Kurumu Uluslar arası Türk Dil Kongresi, Ankara, 26 Eylül-1 Ekim 1992, Özyurt Matbaasl, Ankara, 2002.

Fedai, Harid. Kıbrıs Türk Kültürü Makaleler-1, Kıbrıs Türk Basınında Bir Keçe: Matbaacı Akif Bey, Griffiths, Antony. Prints and Prints Making, an Introduction to the History and Techniques. University of California Press. Los Angles. 1996.

Hall, David. D. Cultures of Print, Essays in the History of the Book.University of Massachusets Press. 1996

Hüdaoğlu, Gürdal. Kıbrıs'ta Siyasal Dönüşüm: Meydandan Medyaya, Doktora Tezi, Yakın Doğu Üniversitesi Sosyal Bilimler Enstitüsü İletişim Yayınları Anabilim Dalı Doktora Programı, Lefkoşa, 2011.

Kızllyürek, Niyazi. Naci Talat ve Kıbrıs Türk Solu, Panel Notlarl, Naci Talat Vakfi Yayınlarl, 2008 Kıbrıs Türk Gazeteciler Birliği. Kıbrıs Türk Basın Tarihi, 2012. 